Artikel Penelitian

\title{
Toksigenitas Corynebacterium diphtheriae Pada Sampel Kejadian Luar Biasa Difteri Tahun 2010 - 2015 Menggunakan Elektes
}

Kambang Sariadji, Sunarno

\begin{abstract}
Abstrak
Strain Corynebacterium diphtheriae dapat dibedakan berdasarkan sifat toksigenisitas atau kemampuannya dalam memproduksi toksin difteri. Jenis C.diphtheriae yang mampu memproduksi toksin disebut jenis toksigenik, sedangkan yang tidak memproduksi toksin disebut jenis non-toksigenik. Diagnosis laboratorium dalam mendeteksi C.diphtheriae dilakukan dengan cara kultur, isolasi dan identifikasi serta penentuan toksigenitas dari difteri. Tujuan penelitian ini adalah menentukan toksigenitas C.diphtheriae pada isolat hasil investigasi kejadian luar biasa antara tahun 2010 sampai 2015. Sebanyak 61 Isolat C.diphtheriae ditumbuhkan dan diidentifikasi kembali, kemudian dilakukan uji toksigenitas dengan cara elektes. Hasil pemeriksaan kultur dan isolasi menunjukkan 57 isolat adalah C.diphtheriae dengan berbagai sub tipe dan 4 isolat adalah Corynebacterium pseudodiphthericum yang merupakan bakteri bersifat komensal di saluran pernapasan atas dan kulit manusia. Hasil elektes dari 57 isolat menunjukkan 54 isolat C.diphtheriae adalah toksigenik dan 3 isolat non toksigenik. Simpulan studi ini ialah isolat C.diphtheriae hasil investigasi KLB didapatkan 54 isolat toksigenik dan 3 isolat non toksigenik.
\end{abstract}

Kata kunci: toksigenitas, C.diphtheriae, elek test

\begin{abstract}
Strains of Corynebacterium diphtheriae are distinguishable based on toxigenicity or capable of producing diphtheria toxin. Type of C.diphtheriae that can produce toxins is called toxigenic species and non-toxigenic species while not producing a toxin. Laboratory diagnosis in detecting of C.diphtheriae was done by culture, isolation and identification, then determination of toxigenicity of diphtheria. The objective of this study was to determine toxigenicity of C.diphtheriae as an outbreaks investigations results from 2010 until 2015. A total of 61 Isolates were re-culture and identified C.diphtheriae, then the detection of toxigenicity test was done by elektest. The result test of Culture and inoculations showed 57 isolates were C.diphtheriae with various subtypes and 4 isolates were Corynebacterium pseudodiphthericum which is to be commensal bacteria in the upper respiratory tract and skin human. The Elek test result from 57 isolates showed 54 were C..diphtheriae with toxigenic and 3 isolates are non-toxigenic. The conclusion is C.diphtheriae Isolates as a results of outbreaks investigation were obtained 54 isolates of toxigenic and 3 isolates non-toxigenic .
\end{abstract}

Keywords: toxigenicity, C. diphtheriae, elek test

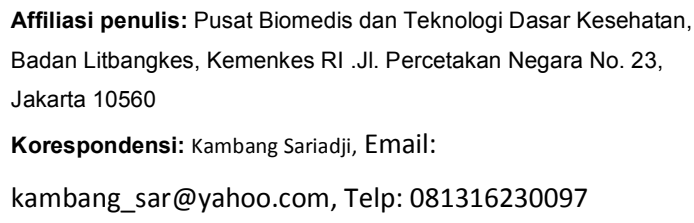

Affiliasi penulis: Pusat Biomedis dan Teknologi Dasar Kesehatan, Badan Litbangkes, Kemenkes RI .Jl. Percetakan Negara No. 23, Jakarta 10560

Korespondensi: Kambang Sariadji, Email:

kambang_sar@yahoo.com, Telp: 081316230097

\section{PENDAHULUAN}

Penyakit difteri ketika timbul di masyarakat akan berdampak fatal bagi penderitanya dan menimbulkan keresahan di lingkungan masyarakat sekitarnya. Penyakit ini sudah dikenal sejak dulu yaitu 
sejak jaman Hippocrates. Hippocrates memberikan gambaran klinis pertama difteri pada abad ke-4 SM. Gambaran klinis modern dibuat oleh Joost van Lom pada tahun 1560 dan Baillou tahun 1576. Mereka menyebut penyakit sebagai 'quinsy' dan 'croup'. Dari Spanyol penyakit menyebar ke Italia tahun 1618 dan dikenal sebagai 'male in canna' atau 'gullet diseases'. $1,2,3$

Dampak fatal infeksi difteri terhadap manusia adalah karena toksin yang dihasilkan. Ketika bakteri masuk dalam tubuh, bakteri difteri akan melepaskan toksin. Toksin ini akan menyebar melalui darah dan bisa menyebabkan kerusakan jaringan di seluruh tubuh,terutama jantung dan saraf. Toksin biasanya menyerang saraf tertentu, misalnya saraf di tenggorokan, sehingga mengalami kesulitan menelan pada minggu pertama akibat dari toksin yang dihasilkan..Kerusakan akibat toksin difteri bisa sangat berat, bahkan menyebabkan gagal jantung dan kematian mendadak. Tidak hanya C.diphtheriae yang menghasilkan toksin difteri, tapi beberapa spesies seperti C. ulcerans dan C.pseudotuberculosis, mempunyai kemiripan protein yang identik dengan toksin yang dihasilkan C.diphtheriae. ${ }^{4,5,6}$

Tahun 1888, Roux dan Yersin menunjukkan adanya toksin pada cairan kultur. Roux dan Yersin yang bekerja pada Pasteur Institute, menyampaikan kebenaran bahwa cairan kultur yang sudah bersih dari mikroorganisme (difilter) yang disuntikkan ke binatang peka dapat menyebabkan semua gejala serupa difteri. Dua tahun kemudian, Emil von Behring dan Kitasato berhasil mengimunisasi marmut dengan toksin yang dilemahkan dengan pemanasan dan menunjukkan bahwa serum binatang yang diimunisasi mengandung antitoksin yang dapat memproteksi binatang lain melawan difteri. Modifikasi toksin ini cocok sebagai imunisasi binatang untuk mendapatkan antitoksin, tapi dapat menyebabkan reaksi lokal berat pada manusia, sehingga tidak bisa digunakan sebagai vaksin. Tahun 1890, Emil von Behring memenangkan Nobel untuk pekerjaannya mengembangkan antitoksin. ${ }^{7}$

Tahun 1913, Bela Schick memperkenalkan tes intradermal untuk menunjukkan ada tidaknya sirkulasi antitoksin. Schick mendisain skin test untuk menilai imunitas dan suseptibilitas difteri pada manusia. ${ }^{7}$
Toksin difteri akan menyebabkan reaksi inflamasi ketika sejumlah kecil diinjeksikan secara intrakutan. Schick test adalah menyuntikkan sejumlah kecil toksin di bawah kulit tangan dan hasilnya dievaluasi dalam 48 jam. Tes positif (reaksi inflamasi) mengindikasikan suseptibilitas. Test negatif berarti mengindikasikan antibodi menetralisasi toksin. ${ }^{7}$

Berdasarkan kemampuan dan sifat toksigenisitas dalam memproduksi toksin difteri, C. diphtheriae dapat dibedakan menjadi dua yakni toksigenik dan non toksigenik. Jenis bakteri yang mampu memproduksi toksin disebut jenis toksigenik, sementara yang tidak memproduksi toksin disebut jenis non-toksigenik. Sifat toksigenisitas ini bisa berubah karena pengaruh bakteriofaga yang membawa gen tox, bakteri non-toksigenik akan berubah menjadi toksigenik ketika diinsersi bakteriofaga tersebut. Strain non-toksigenik sering diisolasi dari komunitas ketika terjadi wabah difteri atau daerah dengan cakupan imunisasi tinggi dan sebagian diantaranya diisolasi dari pasien dengan endokarditis, sepsis, serta beberapa penyakit lainnya. $^{5,8,9}$ Tujuan dari penelitian ini adalah untuk menentukan toksigenitas C.diphtheriae yang tersimpan Laboratorium Bakteriologi Pusat Biomedis dan Teknologi Dasar Kesehatan

Pemeriksaan toksigenitas difteri mempunyai Gold standard dengan menggunakan Guinea pig dan Vero cell cytotoxicity. Saat ini penggunaan Guinea pig banyak ditentang pecinta hewan, sementara penggunaan Vero cell cytotoxicity membutuhkan kelengkapan laboratorium dan keterampilan tenaga yang cukup tinggi serta membutuhkan waktu cukup lama. Alternatif lainnya adalah dengan metode PCR, namun metode ini mempunyai kelemahaan tidak semua gen tox yang terdeteksi dengan PCR dapat mengekpresikan fenotifnya berupa toksin. Pada penelitian ini, tes toksigenisitas dilakukan dengan Elek test sebagai alternatif gold standard. Prinsip pemeriksaan Elek test adalah immunopresipitasi. ADS sebagai antibodi direaksikan dengan toksin difteri sebagai antigen yang dikeluarkan oleh bakteri pada medium kultur. Bila bakteri menghasilkan toksin difteri maka akan terjadi ikatan antigen-antibodi yang membentuk presipitasi. , $^{7,10,11}$ Tes ini sangat penting 
untuk diagnosis difteri dan seharusnya tidak ditunda ketika ditemukan Corynebacterium diphtheriae dari penderita suspek maupun kontak

\section{METODE}

Penelitian dilakukan di Laboratorium Bakteriologi yang berada di Pusat Biomedis dan Teknologi Dasar Kesehatan, Badan Penelitian dan Pengembangan Kesehatan, Kementerian Kesehatan, dari Juni sampai Desember 2015. Sampel yang digunakan adalah isolat $C$.diphtheriae tersimpan hasil investigasi Kejadian Luar Biasa (KLB) dari tahun 2010 sampai 2014 berjumlah 48 isolat dan 13 isolat hasil investigasi KLB tahun 2015, sehingga totalnya 61 isolat. Isolat tersebut ditumbuhkan kembali pada medium selektif cystine tellurite blood agar (CTBA), inkubasi selama $24-48$ jam pada suhu $37^{\circ} \mathrm{C}$. Adanya koloni yang diduga koloni $C$.diphtheriae pada medium CTBA dengan ciri koloni bulat, hitam keabuan divalidasi dengan pemeriksaan mikroskopik menggunakan pewarnaan Albert. Morfologi C.diphtheriae secara mikroskopik menunjukkan gambaran bentuk batang dengan pembesaran (granul) pada salah satu atau kedua ujungnya. Pengujian dilanjutkan dengan uji biokimia dan uji toksigenisitas

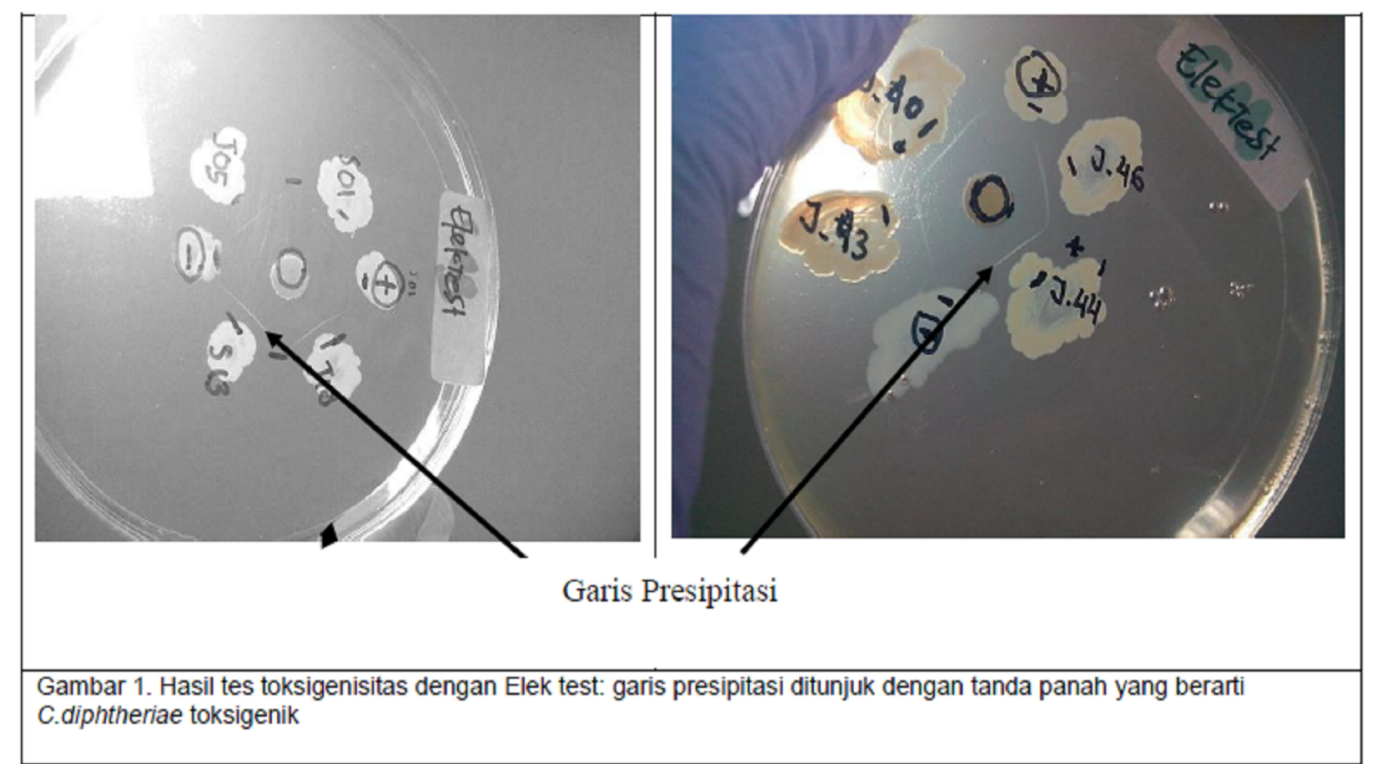

\section{PEMBAHASAN}

Penyakit difteri berawal dari masuknya bakteri penyebab ke dalam tubuh dan berkembang biak pada mukosa saluran nafas atas. Adanya perlekatan bakteri menggunakan isolat murni yang ditumbuhkan kembali dari medium selektif CTBA ke Blood Agar (BA). Uji toksigenitas difteri dilakukan dengan menggunakan metode Elek test. Pemeriksaan elek test dilakukan dengan media elek test pada petri disk diameter 4,5 $\mathrm{cm}$. Disk antitoksin berisi 25 IU ADS (Biofarma) diletakkan di bagian tengah petri, kemudian isolat C.diphtheriae diinokulasi pada bagian tepi dengan jarak $1 \mathrm{~cm}$ dari disk antitoksin. Inkubasi pada suhu $37^{\circ}$ C selama 24-48 jam. ${ }^{7,9,10}$

\section{HASIL}

Total isolat tersimpan berjumlah 61 buah menunjukkan hasil karakteristik koloni difteri pada medium CTBA yakni tampak hitam atau abu-abu. Pemeriksaan tersebut dilanjutkan dengan mikroskopik dan uji biokimia dengan hasil menunjukkan 57 isolat adalah C.diphtheriae dengan berbagai sub tipe dan 4 isolat adalah Corynebacterium pseudodiphthericum. Hasil Elek test dari 57 sampel menunjukkan 54 isolat toksigenik dan 3 isolat menunjukkan hasil non toksigenik. Hasil positif toksigenitas ditandai dengan terbentuknya garis presipitasi, sementara yang non toksigenik tidak menunjukkan garis presipitasi. Empat isolat C.pseudodiphthericum tidak dilakukan uji. 
infeksi, diikuti akumulasi fibrin yang diinfiltrasi oleh leukosit. Sel epitel akan mengalami destruksi dan terbentuk selaput yang dikenal dengan pseudomembran. Ada sebuah hipotesis yang menyatakan bahwa terbentuknya pseudomembran tidak terlepas dari peran toksin difteri yang dihasilkan bakteri penyebab. Hal ini berdasarkan hasil pengamatan yang menemukan bahwa pseudo membran jarang terjadi pada kasus yang disebabkan oleh strain non-toksigenik. ${ }^{4,12,13}$

Tidak semua isolat difteri menghasilkan toksin, oleh karena itu pemeriksaan toksigenisitas pada isolat yang telah ditemukan sangat penting. Jenis bakteri yang mampu memproduksi toksin disebut jenis toksigenik, sementara yang tidak memproduksi toksin disebut jenis non-toksigenik. Hasil penelitian 57 isolat C.diphtheriae tersimpan menunjukkan 54 adalah toksigenik dan 3 nontoksigenik. Strain toksigenik ini bertanggung jawab atas terjadinya komplikasi sistemik. ${ }^{5,8}$

Komplikasi sistemik difteri yang paling sering adalah miokarditis dan polineuropati. Miokarditis biasanya terjadi pada minggu ke-2 dan merupakan penyebab kematian kedua setelah asfiksia. Polineuropati biasanya terjadi minggu ke-3 setelah onset dan dapat mengenai sistem saraf motorik maupun sensorik. Sementara itu, komplikasi dan kasus fatal jarang terjadi pada difteri kulit. ${ }^{14}$

Difteri ditularkan melalui kontak fisik secara langsung atau cairan aerosol dari penderita. Difteri merupakan penyakit fatal yang sangat serius dengan CFR $5-10 \%$. Pada usia di bawah 5 tahun dan dewasa lebih 40 tahun Case Fatality Rate (CFR) bisa mencapai $20 \%{ }^{7}$

Infeksi karena C.diphtheriae non-toksigenik telah diketahui menyebabkan penyakit lokal sejak tahun 1922 dan kadang-kadang juga menyebabkan penyakit sistemik. Ada beberapa laporan bahwa Corynebacterium diphtheriae non toksigenik dapat menyebabkan endokarditis, bakteremia, septic arthritis dan abses limpa. Beberapa kasus Corynebacterium diphtheriae non-toksigenik dihubungkan dengan sakit tenggorok dan membran tonsil. Kasus non-toksigenik sering berkaitan dengan faringitis pada homoseksual dengan penyakit urogenital. Penelitian sebelumnya melibatkan 238 sampel (211 sakit tenggorok) menemukan Corynebacterium diphtheriae nontoksigenik pada $72 \%$ sampel, Streptococcus Bhemolotikus pada $28 \%$ sampel dan virus pada $4 \%$ sampel. Masih sangat sedikit pengetahuan tentang patogenisitas Corynebacterium diphtheriae nontoksigenik, diperkirakan bakteri mempunyai afinitas dan menyerang endotel vaskuler. Meskipun demikian, jenis nontoksigenik dapat menyebabkan penyakit yang mematikan, seperti endokarditis dan dapat berubah menjadi toksigenik sehingga keberadaannya harus diwaspadai. ${ }^{10,15}$

Uji toksigenisitas secara in vivo dan in vitro dengan sel vero cukup akurat, namun memerlukan waktu lama. Tes invivo juga dapat dilakukan dengan Guinea pig yang merupakan gold standard. Biaya dan resiko kecelakaan saat inokulasi membuatnya tidak aplikatif. Beberapa metode yang sering dipakai adalah dengan cara Elek test dan metode molekular Polymerase chain Reaction, namun metode PCR mempunyai kelemahan yakni tidak semua C.diphtheriae yang mempunyai gen tox dapat mengekpresikan toksinnya, sehingga perlu dilakukan uji ulang dengan metode elek test. ${ }^{7,11}$

Pada penelitian ini juga ditemukan empat isolat C.pseudodiphthericum yang merupakan jenis bakteri non difteri dan tidak patogen pada manusia. Bakteri ini bersifat komensal di saluran pernapasan atas dan kulit, lebih dikenal sebagai patogen oportunistik pada predisposisi pasien dengan kondisi penyakit ginjal kronis, tranplantasi ginjal, infeksi HIV, keganasan dan sirosis hati. ${ }^{16}$

\section{SIMPULAN}

Pada deteksi toksigenitas C.diphtheriae terhadap isolat difteri tersimpan didapatkan 54 isolat C..diphtheriae toksigenik dan 3 isolat non toksigenik, sementara 4 isolat merupakan C.pseudodiphthericum tidak dilakukan pengujian toksigenitas.

\section{SARAN}

Dalam menegakan diagnosis difteri, laboratorium mikrobiologi hendaknya melakukan serangkaian metode pemeriksaan mulai dari mikroskopik, kultur,identifikasi lanjut dengan pengujian 
biokimia API coryne dan tidak mengabaikan uji toksigenitas. Tes ini sangat penting untuk diagnosis difteri dan seharusnya tidak ditunda ketika ditemukan C.diphtheriae dari penderita suspek maupun kontak.

\section{UCAPAN TERIMA KASIH}

Terima kasih kepada Kepala Pusat Biomedis dan Teknologi Dasar Kesehatan, serta kawan - kawan Laboratorium Bakteriologi Pusat Biomedis dan Teknologi Dasar Kesehatan yang telah membantu selama proses penelitian menggunakan spesimen KLB difteri yang tersimpan.

\section{DAFTAR PUSTAKA}

1. Lumio J. Studies on the epidemiology and clinical characteristics of diphteria during the Russian epidemic of the 1990s (dissertation). Finlandia: University of Tampere; 2003.

2. Nandi R, Purkayastha P, Bhattacharjee AK. Diphtheria: the patch remains. International Congress series. 2003;1254:391-7.

3. Guilfoile PG. Deadly diseases and epidemics: diphtheria. New York: Chelsea House Publishers; 2009.

4. Acang N. Difteri. Dalam: Noer HMS, editor (penyunting). Ilmu Penyakit Dalam Jilid 1. Edisi ke3. Jakarta: Balai Penerbit FKUI; 1996.

5. De Zoysa A \& Efstratieu A. Corynebacterium spp. Dalam: Gillespie SH, Hawkey PM, editor (penyunting). Principles and Practice of Clinical bacteriology. Edisi ke-2. USA: John Wiley \& Son, Ltd; 2006.

6. Zasada AA, Zaleska M, Podlasin RB, Seferyńska I. The first case of septicemia due to nontoxigenic Corynebacterium diphtheriae in Poland: case report. Annals of Clinical Microbiology and Antimicrobials. 2005;4:8.
7. Rudi HP, Sariadji K, Sunarno, Roselinda. Corynebacterium diphtheriae: diagnosis laboratorium bakteriologi. Edisi ke-1. Yayasan Pustaka Obor Indonesia; 2014.

8. Efstratiou A, George RC. Laboratory guidelines for the diagnosis of infections caused by Corynebacterium diphtheriae and C. ulcerans. Commun Dis Public Health. 1999;2:250-7.

9. Efstratiou A, Engler KH, Mazurova IK, Glushkevich T, Vuopio-Varkila J,Popovic T. Current approaches to the laboratory diagnosis of diphtheria. JID. 2000;181(Suppl 1):S138-45.

10. Elek test for detection of toxigenic corynebacteria in the diagnostic laboratory. J.Clin. Mirobiol. 1997;35(2):495-8.

11. Handayani S. Deteksi kuman difteri dengan polymerase chain reaction (PCR). CDK-191. 2012; 39(3).

12. Holmes KR. Diphtheria. Dalam: Fauci AS, et al. editor (penyunting). Harrison's Principles of Internal Medicine. Edisi ke-17. McGrow-Hills; 2008.

13. Burkovski A. Diphtheria and its etiological agent. Dalam: Burkovski A, editor (penyunting). Corynebacterium diphtheriae and Related Toxigenic Species. Springer; 2014.

14. Markina SS, Maksimova NM, Vitek CR, Bogatyreva EY, Monisov AA. Diphtheria in the Russian federation in the 1990s. The Journal of Infectious Diseases. 2000;181(Suppl 1):S27-34.

15. Engler KH, Glushkevich T, Mazurova IK, George $\mathrm{RC}$ and Efstratiou A. Elek SD. The Plate virulence test for diphtheria. J. Clin. Path. 1949;2:250-8.

16. Olinder A, Antibiotic resistance and detection of the most common mechanism of resistance (MLSB) of opportunistic corynebacterium. Chemotherapy 2013;59:294-306. 